\title{
TRANSFER OF SOME TOXIC METALS FROM SOIL TO HONEY DEPENDING ON BEE HABITAT CONDITIONS
}

\author{
- Research paper -
}

\author{
Monika TOMCZYK*, Grzegorz ZAGUŁA ${ }^{* *}$, Czesław PUCHALSKI**, Małgorzata DŻUGAN \\ *Department of Chemistry and Food Toxicology, Institute of Food Technology and Nutrition, \\ University of Rzeszów, Ćwiklińskiej 1a St., 35-601 Rzeszów, Poland \\ ** Department of Bioenergetics and Food Analysis, Institute of Food Technology and Nutrition, \\ University of Rzeszów, Zelwerowicza 4 St., 35-601 Rzeszów, Poland
}

\begin{abstract}
The transfer of toxic metals from soil to honey was studied based on two different areas of the Podkarpackie region located in the south-east part of Poland: U-urbanized and E-ecologically pure. The metal content was determined using the ICP-OES method with prior microwave mineralization of the soil, plant (goldenrod, dandelion, rapeseed, tilia and fir), bee bodies and honey samples collected from 10 sampling points (U-5 and E-5). The impact of soil pH on heavy metal mobility was also evaluated. It was found that Podkarpackie soils are less contaminated with heavy metals as compared to other regions of Poland and only in the case of cadmium an enhancement of the natural background level was observed. The migration of heavy metals, especially cadmium, in the soil-plant-bee-honey food chain was accelerated by soil acidity $(\mathrm{p}<0.05)$. The influence of human activity (region development) on heavy metals concentrations was not significant $(\mathrm{p}>0.05)$. Based on bioaccumulation factors, goldenrod and dandelion plants were confirmed as cadmium accumulators. It was also confirmed that the bodies of bees act as an effective barrier to the migration of heavy metals from the environment to honey, due to this, honey is free from these metals and safe for human consumption.
\end{abstract}

Key words: honey, heavy metals, soil, melliferous plant, food chain

\section{INTRODUCTION}

The accumulation of toxic metals in agricultural soils results from industrialization and other anthropogenic sources, mainly the metallurgy industry, energy and fuel production, traffic activities, intensive agriculture and sludge usage (Mirecki et al., 2015; Yan et al., 2018; Ali et al., 2019). The solubility of trace elements depends on various factors such as the presence of minerals and organic matter in the soil, soil $\mathrm{pH}$, redox potential, physical and mechanical properties, soil temperature and humidity (Violante et al., 2010; Draszawka-Bołzan, 2015). Moreover, different processes, such as adsorption, ionic exchange, redox reaction or precipitation affect the uptake of soil pollutants by plants (Smical et al., 2008; Jin et al., 2018). The level of absorption of heavy metals by plants depends upon the plant species and its growth stages as well as soil type. Regardless of the mechanism of the transfer of

Received: 20.12.2019.

Accepted in revised form: 22.04.2020 toxic metals from soil to plants, their presence induces morphological and structural changes in plant organs. Poorly mobile elements (as $\mathrm{Cr}, \mathrm{Cu}$, $\mathrm{Pb}$ ) mainly damage the roots and indirectly the leaves, meanwhile elements with greater mobility $(\mathrm{Cd}, \mathrm{Ni}, \mathrm{Zn})$ affect foliage directly causing more visible symptoms (Gostin, 2010).

Plants contaminated with heavy metals may be introduced directly into the human food chain, but they can also cause an additional indirect threat through pollinators being exposed to contaminated plants. (Afzal et al., 2013; Ali et al., 2019). Even when the environmental concentration of heavy metals is lower than the minimal risk levels for human health it may still be a relevant danger to pollinator activity and survival (Burden et al., 2019). Thus, the determination of heavy metal concentrations in honey bee (Apis mellifera) bodies, could serve as an intermediate parameter in the environmental biomonitoring of toxic metal pollution (Skorbiłowicz et al., 2018; Dżugan et al.,

\footnotetext{
${ }^{1}$ Corresponding author. E-Mail address: mdzugan@ur.edu.pl
} 
2018). The ability to monitor the environment purity with bees is possible for the following reasons: a large flying area $(2-3 \mathrm{~km}$ in diameter of the apiary), the penetration of areas inaccessible to humans, a high reproductive rate and sensitivity to toxic substances (Dżugan et al., 2018).

Bee products are the next link in the food chain and the level of their contamination with heavy metals is directly related to both: the exposure of bees and plants to pollution by these elements (Naggar et al., 2013). Bees collect heavy metals with plant nectar and pollen, and accumulate them in their bodies. However, during intensive contamination this biological barrier can be ineffective and does not protect honey from contamination (Dżugan et al., 2018). For this reason, many authors have attempted to use honey to monitor environmental pollution (Naggar et al., 2013; Oroian et al., 2016; Skorbiłowicz et al., 2018; Dżugan et al., 2018). However, the most important reason for controlling the presence of heavy metals in honey, is to protect the health of consumers (Aghamirlou et al., 2015).

For this reason, the aim of the research was to monitor the intensity of toxic metal transfer from the soil to honey via plant and bees with regard to the ecological quality of the bee habitat.

\section{MATERIAL AND METHODS}

\section{Sampling area}

Two different sampling areas were designated on the map of the Podkarpacie region located in south-eastern Poland based on the intensification of its development: U-urbanized and Eecologically pure. In each area five local apiaries were selected as sampling points. The exact location of each apiary was recorded using a Garmin eTrex10 satellite receiver (Figure 1).

\section{Soil}

During beekeeping season, soil samples $(n=3)$ were collected from each sampling point precisely from the fields where melliferous plants were grown (not more than $1.5 \mathrm{~km}$ from the apiary). Then, representative soil samples from a depth of $0-10 \mathrm{~cm}$ were taken. Before analysis the soil samples were dried at $60^{\circ} \mathrm{C}$ in a laboratory dryer until a constant weight was achieved. Then the non-humified parts (roots) were removed, the soil was ground in a mortar, sieved through a $2 \mathrm{~mm}$ sieve and preserved in polyethylene bags in a desiccator pending further analysis.

\section{Plants}

Bee forage plants (goldenrod 10, dandelion 10, rapeseed 10 , tilia 10 and fir needle 10) were collected within an area of $0-1.5 \mathrm{~km}$ radius around the apiary at the same points where the soil was sampled. Fully developed inflorescences ( 5 per each plant species) were collected in the middle of the flowering season based on the advice of beekeepers. Fir needles (50g) were collected during honeydew secretion. The plant material was dried at $60^{\circ} \mathrm{C}$ in a laboratory dryer until a constant weight was achieved and then ground in a laboratory grinder. The powder obtained was stored in polyethylene bags in a desiccator pending further analysis.

\section{Honey bees (Apis mellifera L.)}

Honey bee worker samples $(n=30)$ were collected three times during the June-July period in regular two-week intervals from every sampling point. After fumigation, bees were carefully brushed into disposable polyethylene bags. On each occasion at least 100 individuals were sampled from the honeycombs placed on the farthest sidewalls of the hive. Next, bee samples were transported to laboratory and frozen at $-4^{\circ} \mathrm{C}$. Before analysis, the bee samples were dried until a constant weight was achieved (moisture analyser at $105^{\circ} \mathrm{C}$ ) and ground with a manual laboratory grinder.

\section{Honey samples}

Fifty honey samples were taken in total, including five honey varieties collected from each sampling point in the $\mathrm{E}$ and $\mathrm{U}$ areas. The tested materials contained 10 dandelion, 10 rapeseed, 10 goldenrod, 10 tilia and 10 honeydew honeys. The honey variety was determined by a beekeeper according to the nectar flow availability. The honey samples were stored at $21^{\circ} \mathrm{C} \pm 2$ in tightly closed glass jars until the time of analysis.

\section{Elements determination}

The concentration of the 5 chosen metals $(\mathrm{Cd}, \mathrm{Pb}$, $\mathrm{Hg}, \mathrm{Al}, \mathrm{Ni}$ ) were determined by optical emission spectrometry with inductively induced plasma (ICP-OES) using a Thermo iCAP 6500 spectrophotometer (Thermo Fisher Scientific Inc., Bridgewater, USA) regardless of the sample type. Prior to spectrometry analysis, the samples were mineralized in a microwave mineralizer Milestone Ethos Ultrawave-One (Milestone SRL, Sorisole, 
Italy). For this purpose, $1 \mathrm{~g}$ of sample (honey, plants and bees) was weighed in Teflon vessels, and then $8 \mathrm{ml}$ of concentrated $\mathrm{HNO}_{3}(65 \%$ purebasic, POCH Gliwice) was added. In the case of soil samples, two different metal fractions were examined. In the case of the total metal content, the soil sample was mineralized with $8 \mathrm{ml}$ of aqua regia $\left(2 \mathrm{ml}\right.$ concentrated $\mathrm{HNO}_{3}$ and $6 \mathrm{ml}$ concentrated $\mathrm{HCl}$ ), whereas for the absorbable forms of the metals in the soil, an extract in $1 \mathrm{M}$ $\mathrm{NH}_{4} \mathrm{NO}_{3}$ solution was used. The process of mineralization lasted about 30 minutes. Cooled samples were transferred to sterile flasks $(50 \mathrm{ml}$ volume) and made up to the mark with distilled water. The detection threshold for each element was at least $0.01 \mathrm{mg} \mathrm{kg}^{-1}$ based on the assumed detection capacity of the device used at a level above $1 \mathrm{ppb}$ ). The curve fit factor for the elements studied was above 0.99. Analyses were made independently in triplicate. The targeted repeatability (RSD) and recovery were 20 and 97 to $102 \%$, respectively. For method validation a certified reference material (NIST -1515) was used. The method of internal standard addition was applied to identify the analytical line and to avoid interferences. Yttrium $\left(2 \mathrm{mg} \mathrm{dm}{ }^{-3}\right)$ and ytterbium $\left(5 \mathrm{mg} \mathrm{dm}^{-3}\right)$ were used as internal standards. The results were expressed as mg per kg dry weight (d.w.) of soil, plants and bees and $\mathrm{mg}$ per $\mathrm{kg}$ for honey.

\section{Soil pH determination}

Soil $\mathrm{pH}$ was measured using an Elmetron C-410 $\mathrm{pH}$ meter. Briefly, $25 \mathrm{ml}$ of $1 \mathrm{M} \mathrm{KCl}$ solution was added to $10 \mathrm{~g}$ of dried soil and shaken thoroughly. After 15 minutes, the $\mathrm{pH}$ of the suspension was measured.

\section{Data analysis \\ Bioaccumulation factor}

The metal concentration in the soils and plants were calculated per $100 \mathrm{~g}$ d.w. The plant bioaccumulation factor $(\mathrm{BF})$ was calculated using the formula:

$$
\mathrm{BF}=\mathrm{C}_{\text {plant }} / \mathrm{C}_{\text {soil }}
$$

where $\mathrm{C}_{\text {plant }}$ metal concentration in $100 \mathrm{~g}$ d.w. of plants; $\mathrm{C}_{\text {soil- }}$ metal concentration in $100 \mathrm{~g}$ d.w. of soil.

\section{Metal concentration visualization}

Based on the calculated bioaccumulation factors, the areas of increased migration of toxic elements from soil to plants have been designated on the map of the Podkarpackie Voivodeship. The projection was made using Surfer v12 software.

\section{Statistical analysis}

The significant differences $(\mathrm{p}<0.05)$ for the average concentration of the tested metals, in particular, links in the food chain between $U$ and $E$ regions as well as between the mean values of the tested materials were determined using one-way analysis of variance (ANOVA) combined with Tukey's multiple range test. The relationships between tested element concentrations in analysed biological materials were estimated based on Pearson's correlation coefficients. All data were analysed using Statistica 13.1 software.

\section{RESULTS AND DISCUSSION}

\section{Concentration of toxic metals in the individual links of the food chain}

The study was focused on the examination of the impact of the anthropogenic modification of bee habitat on honey contamination with heavy metals. The two tested areas: U-urbanized and Eecologically pure were selected based on earlier findings (Dżugan et al., 2018), they are located in the Podkarpacie region (south-eastern Poland) adjacent to Ukraine and Slovakia. The chosen region is considered to be the most environmentally unspoilt regions in Poland having the highest purity water. However, an elevated geochemical background of cadmium in the Podkarpackie soil resulting from its origin from the natural bedrock (Carpathian flysch) was reported (Reszel et al., 2003). Moreover, in recent times some parts of the Podkarpackie region have been characterized by intensive economic and urban development which has resulted in increasing air contamination.

\section{Soil contamination by toxic metals}

The $\mathrm{pH}$ of the tested soils showed that they ranged from slightly acidic to very acidic and the more acidic soil originated from the U-region $(\mathrm{pH} 4.64)$ in comparison with the E-region ( $\mathrm{pH}$ 5.20; Table 1). As the sampling points in the $U$ area were located close to urban agglomerations whereas $\mathrm{E}$ was in a rather rural area, the observed differences in soil $\mathrm{pH}$ seem to be the effect of anthropogenic activity. However, despite the huge variation in the content of the tested toxic metals in soil significant differences between the designated areas ( $\mathrm{E}$ and $\mathrm{U}$ ) were not observed $(p>0.05)$. The total concentration of toxic metals in the tested soil was 
significantly higher as compared to their available fraction (Table 1). The share of the available fraction of $\mathrm{Cd}$ and $\mathrm{Ni}$ was higher for the E-region and accounted for between 36 and $24 \%$ of the total as compared to the U-region which reached 26 and $14 \%$, respectively. The opposite observation was made for $\mathrm{Pb}, \mathrm{Al}$ and $\mathrm{Mn}$ where the available fraction made up a slightly higher share of the aforementioned metals found in the U-region (4, 3 and $7 \%$ ) in comparison with the E-region (1,2 and $5 \%)$.

The observed variability in the content of $\mathrm{Al}$, considered to be a neurotoxin for humans with a tolerable weekly intake set by the European Food Safety Authority (EFSA) as $1 \mathrm{mg}$ aluminium $/ \mathrm{kg}$ body weight (Klotz et al., 2017), seems to indicate the presence of man-made local pollution.

However, as determined in the present study, the concentrations of $\mathrm{Pb}$ and $\mathrm{Cd}$ in most of the samples were below the limits established for soil set by the Polish regulations of the Minister of the Environment (2002), where the maximum permissible levels of heavy metals in soil were set as 4, 100, $100 \mathrm{mg} / \mathrm{kg} \mathrm{d.w}$. for $\mathrm{Cd}, \mathrm{Pb}$ and $\mathrm{Ni}$ respectively. When comparing the presented results to the findings of other authors concerning toxic metals in soil samples from different regions in Poland, it may be stated that Podkarpackie soil is moderately contaminated with $\mathrm{Cd}$ and less polluted with $\mathrm{Pb}$.

Dabkowska-Naskret et al. (2016) sampled soil from the park areas in Bydgoszcz city located in the unspoilt north-west region of Poland and found a comparable level of Cd $(0.3-1.2 \mathrm{mg} / \mathrm{kg}$ d.w.) but higher levels of $\mathrm{Pb}(5.4-148.9 \mathrm{mg} / \mathrm{kg}$ d.w.). In turn, for Silesia, the region in Poland most polluted by the non-ferrous metal industry, significantly higher levels of $\mathrm{Cd}$ (up to 12.32 $\mathrm{mg} / \mathrm{kg}$ d.w.) and $\mathrm{Pb}$ (up to $781.91 \mathrm{mg} / \mathrm{kg}$ d.w.) were reported in soils (Diatta et al., 2008; Miśkowiec et al., 2015). Thus, this study confirmed the high ecological quality of Podkarpackie soils, naturally rich in cadmium. However, the Cd level found in Podkarpackie soils is far from the limit of $3 \mathrm{mg} / \mathrm{kg}$ d.w. reported by Buczkowski et al. (2002) as a toxic concentration to plants.

Table 1. Concentration of toxic metals ( $\mathrm{mg} / \mathrm{kg}$ d.w.) in tested soil (total and available) and plant samples collected from ecological (E) and urbanized (U) regions of Podkarpacie. The results are expressed as mean \pm SD and (min-max) values

\begin{tabular}{|c|c|c|c|c|c|c|c|}
\hline \multicolumn{2}{|r|}{ Sample } & Area & Cd & $\mathbf{P b}$ & Al & Mn & $\mathbf{N i}$ \\
\hline \multirow{4}{*}{$\overline{0}$} & \multirow{2}{*}{ total } & $\begin{array}{c}\text { E pH 5.2 } \pm 1.1 \\
(4.2-7.3)\end{array}$ & $\begin{array}{c}0.39 \pm 0.29 \\
(0.08-1.50)\end{array}$ & $\begin{array}{c}19.25 \pm 7.21 \\
(9.23-39.83)\end{array}$ & $\begin{array}{c}2706.27 \pm 685.00 \\
(2447.35-3789.73)\end{array}$ & $\begin{array}{c}531.80 \pm 263.29 \\
(80.29-1030.00)\end{array}$ & $\begin{array}{c}1.03 \pm 2.73 \\
(0.00-9.01)\end{array}$ \\
\hline & & $\begin{array}{c}\mathrm{UpH} 4.6 \pm 1.0 \\
(3.4-6.8)\end{array}$ & $\begin{array}{c}0.35 \pm 0.26 \\
(0.04-1.15)\end{array}$ & $\begin{array}{l}23.35 \pm 11.22 \\
(9.89-58.07)\end{array}$ & $\begin{array}{c}2392.78 \pm 448.10 \\
(1816.73-3444.41)\end{array}$ & $\begin{array}{l}525.94 \pm 253.00 \\
(56.44-956.47)\end{array}$ & $\begin{array}{c}2.25 \pm 5.00 \\
(0.00-16.18)\end{array}$ \\
\hline & \multirow{2}{*}{ available } & $\mathrm{E}$ & $\begin{array}{c}0.14 \pm 0.12 \\
(0.02-0.41)\end{array}$ & $\begin{array}{l}0.20 \pm 0.27^{\mathrm{a}} \\
(0.00-0.93)\end{array}$ & $\begin{array}{c}53.95 \pm 71.86 \\
(0.00-289.50)\end{array}$ & $\begin{array}{l}25.97 \pm 24.24 \\
(0.85-70.23)\end{array}$ & $\begin{array}{c}0.25 \pm 0.37 \\
(0.00-1.50)\end{array}$ \\
\hline & & $\mathrm{U}$ & $\begin{array}{c}0.09 \pm 0.07 \\
(0.01-0.27)\end{array}$ & $\begin{array}{l}0.93 \pm 1.83^{\mathrm{b}} \\
(0.00-7.63)\end{array}$ & $\begin{array}{c}77.55 \pm 96.27 \\
(0.00-348.25)\end{array}$ & $\begin{array}{c}34.26 \pm 48.01 \\
(0.33-221.35)\end{array}$ & $\begin{array}{c}0.32 \pm 0.52 \\
(0.00-1.67)\end{array}$ \\
\hline \multirow{10}{*}{ 䔍 } & \multirow{2}{*}{ Fir } & E & $\begin{array}{c}0.29 \pm 0.20 \\
(0.03-0.63)\end{array}$ & $\begin{array}{c}1.05 \pm 0.49 \\
(0.42-2.02)\end{array}$ & $\begin{array}{c}505.62 \pm 167.39 \\
(142.60-803.19)\end{array}$ & $\begin{array}{c}681.16 \pm 406.18 \\
(95.77-1394.39)\end{array}$ & $\begin{array}{c}1.74 \pm 2.11 \\
(0.00-5.65)\end{array}$ \\
\hline & & $\mathrm{U}$ & $\begin{array}{c}0.50 \pm 0.32 \\
(0.07-1.21)\end{array}$ & $\begin{array}{c}0.66 \pm 0.52 \\
(0.05-1.75)\end{array}$ & $\begin{array}{l}401.52 \pm 249.55 \\
(97.81-792.39)\end{array}$ & $\begin{array}{c}542.01 \pm 502.64 \\
(51.16-1425.68)\end{array}$ & $\begin{array}{c}3.13 \pm 2.21 \\
(0.78-8.99)\end{array}$ \\
\hline & \multirow{2}{*}{ Goldenrod } & $\mathrm{E}$ & $\begin{array}{c}0.48 \pm 0.31 \\
(0.07-0.99)\end{array}$ & $\begin{array}{c}0.57 \pm 0.17 \\
(0.41-0.89)\end{array}$ & $\begin{array}{c}128.29 \pm 90.33 \\
(31.86-284.64)\end{array}$ & $\begin{array}{l}127.23 \pm 111.67^{\mathrm{a}} \\
(24.18-325.00)\end{array}$ & $\begin{array}{c}0.01 \pm 0.03 \\
(0.00-0.10)\end{array}$ \\
\hline & & $\mathrm{U}$ & $\begin{array}{c}0.77 \pm 0.17 \\
(0.59-1.04)\end{array}$ & $\begin{array}{c}0.62 \pm 0.36 \\
(0.07-1.14)\end{array}$ & $\begin{array}{c}108.58 \pm 43.75 \\
(56.16-152.54)\end{array}$ & $\begin{array}{c}537.47 \pm 305.23^{\mathrm{b}} \\
(136.78-1058.26)\end{array}$ & $\begin{array}{c}0.15 \pm 0.33 \\
(0.00-0.82)\end{array}$ \\
\hline & \multirow{2}{*}{ Dandelion } & $\mathrm{E}$ & $\begin{array}{c}0.64 \pm 0.64 \\
(0.13-1.74)\end{array}$ & $\begin{array}{c}0.46 \pm 0.37 \\
(0.00-0.85)\end{array}$ & $\begin{array}{l}274.91 \pm 183.26 \\
(22.75-511.71)\end{array}$ & $\begin{array}{c}53.46 \pm 21.98 \\
(29.17-84.82)\end{array}$ & $\begin{array}{c}1.58 \pm 2.23 \\
(0.00-5.37)\end{array}$ \\
\hline & & $\mathrm{U}$ & $\begin{array}{c}0.44 \pm 0.34 \\
(0.06-1.13)\end{array}$ & $\begin{array}{c}0.48 \pm 0.56 \\
(0.03-1.89)\end{array}$ & $\begin{array}{c}452.87 \pm 642.39 \\
(80.17-2104.41)\end{array}$ & $\begin{array}{c}47.97 \pm 27.43 \\
(19.92-95.95)\end{array}$ & $\begin{array}{c}2.25 \pm 3.20 \\
(0.00-7.48)\end{array}$ \\
\hline & \multirow{2}{*}{ Rapeseed } & E & $\begin{array}{c}0.15 \pm 0.04 \\
(0.12-0.20)\end{array}$ & $\begin{array}{c}0.06 \pm 0.09 \\
(0.00-0.18)\end{array}$ & $\begin{array}{c}36.55 \pm 17.50 \\
(21.38-55.70)\end{array}$ & $\begin{array}{c}28.90 \pm 7.27 \\
(23.39-39.61)\end{array}$ & $\begin{array}{c}0.25 \pm 0.67 \\
(0.00-1.58)\end{array}$ \\
\hline & & $\mathrm{U}$ & $\begin{array}{c}0.20 \pm 0.20 \\
(0.04-0.70)\end{array}$ & $\begin{array}{c}0.04 \pm 0.06 \\
(0.00-0.17)\end{array}$ & $\begin{array}{c}45.69 \pm 28.54 \\
(8.39-105.21)\end{array}$ & $\begin{array}{c}41.21 \pm 19.13 \\
(20.69-71.82)\end{array}$ & $\begin{array}{c}0.46 \pm 0.90 \\
(0.00-2.63)\end{array}$ \\
\hline & \multirow{2}{*}{ Tilia } & E & $\begin{array}{c}0.18 \pm 0.20 \\
(0.06-0.47)\end{array}$ & $\begin{array}{c}0.19 \pm 0.16 \\
(0.01-0.36)\end{array}$ & $\begin{array}{l}64.32 \pm 21.60^{\mathrm{a}} \\
(43.85-91.14)\end{array}$ & $\begin{array}{c}108.65 \pm 49.07 \\
(73.95-143.34)\end{array}$ & n.d. \\
\hline & & $\mathrm{U}$ & $\begin{array}{c}0.16 \pm 0.08 \\
(0.05-0.24)\end{array}$ & $\begin{array}{c}0.32 \pm 0.33 \\
(0.00-0.77)\end{array}$ & $\begin{array}{c}28.00 \pm 6.41^{b} \\
(20.60-31.72)\end{array}$ & $\begin{array}{c}78.95 \pm 84.72 \\
(19.98-176.04)\end{array}$ & n.d. \\
\hline
\end{tabular}

$\mathrm{a}, \mathrm{b}-$ means with various letters are significantly different $(\mathrm{p}<0.05)$ between $\mathrm{E}$ and $\mathrm{U}$ region in particular biological material 


\section{Plants contamination by toxic metals}

Fir needles were found to be the most susceptible to contamination by the tested metals, while the most uncontaminated plant parts were the aerial parts of rapeseed (Table 1). Moreover, the contamination of plants by toxic metals was not dependent on the development intensity of the region, the differences between the $\mathrm{E}$ and $\mathrm{U}$ regions were insignificant $(\mathrm{p}>0.05)$. The high concentration of $\mathrm{Pb}, \mathrm{Al}, \mathrm{Mn}$ and $\mathrm{Ni}$ in the fir needles could be a result of their effective transfer from soil as well as atmospheric deposition (Gandois \& Probst, 2012). Moreover, the presence of sticky wax on the surface of the needles could act as a glue for pollutants (Gostin, 2010). However, the exact cause of such high fir needle contamination is difficult to assess. Taking into consideration the comparable $\mathrm{Cd}$ content in soil samples from the $\mathrm{E}$ and $\mathrm{U}$ regions indicates that the lower $\mathrm{Cd}$ content in fir needles in the $\mathrm{E}$ region is not associated with the purity of the soil but more likely with air pollution. The specific susceptibility to heavy metal contamination by Abies alba needles has been confirmed in the studies of Gandois and Probst, (2012), who tested levels of $\mathrm{Al}$ and $\mathrm{Ni}$ similar to those of the present study, and slightly lower levels of $\mathrm{Cd}, \mathrm{Pb}$ and $\mathrm{Mn}$. Among the melliferous plants, for goldenrod (Solidago) a particularly high accumulation of cadmium was found. However, the differences between samples collected from the $\mathrm{E}$ and $\mathrm{U}$ regions were not significant $(p>0.05)$. It was confirmed that the common dandelion (Taraxacum officinale) is a lead concentrator $(\mathrm{p}<0.05)$. Despite the high $\mathrm{Cd}$ content found in the examined samples of goldenrod, the results of the present research are much lower than those found by Tóth et al. (2012), who tested the level of $\mathrm{Cd}$ in goldenrod leaves from Hungary and found it to be about $1.4 \mathrm{mg} / \mathrm{kg}$ d.w. In turn, common dandelion is considered to be a useful reference point in heavy metal environmental monitoring, due to the fact that it is a widespread species in all temperate regions of the world, as a ubiquitous wild plant of gardens, meadows, lawns, road-sides, and ruderal habitats, often growing on heavily polluted sites, such as railway tracks or in the dusty surroundings of industrial plants (Ligocki et al., 2011). Studies have shown that among the examined plants, the dandelion is characterized by an especially high content of $\mathrm{Cd}, \mathrm{Al}$ and $\mathrm{Ni}$, which indicates the susceptibility of this plant to the accumulation of the aforementioned elements. Kajka and Rutkowska (2018) tested for toxic metals in the above ground parts of dandelion which grow near roads with a high traffic intensity in central Poland and found significantly higher levels of $\mathrm{Ni}$ (4-7 $\mathrm{mg} / \mathrm{kg}$ d.w.) and concentrations of $\mathrm{Cd}$ and $\mathrm{Pb}$ comparable to the present study $(0.3-1$ and 0.15 to $0.7 \mathrm{mg} / \mathrm{kg}$ d.w., respectively). On the other hand, Ligocki et al. (2011) tested the metal content in the leaves of dandelion from the urbanized and village regions in the north part of Poland and found levels significantly lower than the present study of $\mathrm{Cd}, \mathrm{Pb}$, and $\mathrm{Ni}$ and comparable to the present study concentrations of Mn. However, similarly to the present study, authors did not find any significant differences between the samples collected from differently polluted regions.

In the literature Brassica napus is known to exhibit a tendency to accumulate metals, especially toxic ones (Angelova et al., 2017). The authors assert that rapeseed roots are specific accumulators of toxic metals, whereas the aboveground parts do not exhibit such strong properties. Yu et al. (2012) reported of Brassica napus that the aboveground parts had a comparable level of $\mathrm{Cd}$ to the present study $(0.168 \mathrm{mg} / \mathrm{kg}$ d.m. $)$ while higher levels of $\mathrm{Pb}$ and $\mathrm{Ni}$ were present $(0.416$ and $0.76 \mathrm{mg} / \mathrm{kg}$ d.m., respectively) On the other hand, Niedźwiecka and Zamorska-Wojdyła (2017) did not detect $\mathrm{Pb}$ in Brassica napus growing near power plants.Tilia, as the only leafy tree tested was characterized by a relatively low content of the analysed elements, and was the only plant where Ni was not detected. Similar observations have been made by Tomašević et al. (2004). In turn, Šijacic-Nikolic et al. (2012) found in the leaves of tilia trees growing along the highway significantly higher levels of $\mathrm{Ni}$ and $\mathrm{Pb}$ (0.52-2.91 and 1.14-6.27 mg/kg d.m., respectively) and lower levels of Mn (12.12-74.87 $\mathrm{mg} / \mathrm{kg} \mathrm{d.m}$.) as compared to the present study. The same authors stated that the contents of trace elements in tilia leaves are primarily influenced by the genotype when they grow in the same soil conditions.

The variable concentrations of heavy metals in different plant species indicate the different absorption abilities of pollutants from the environment (Kajka and Rutkowska, 2018). It was confirmed by Filipović-Trajković et al. (2012) that based on metal distribution in plant organs, it is possible to assess heavy metal migration from soil to plant. Moreover, Petryk (2016) indicated that the intensity of element uptake and release by plants is significantly affected by soil composition.

\section{Bee body contamination with toxic metals}

Bees can come into contact with toxic metals not only through contaminated water, but also during the collection of contaminated nectar and pollen from plants (Van der Steen et al. 2012; Costa et al., 
2019). A similar concentration of tested metals was found in bee bodies collected from urbanized (U) and ecological (E) regions ( $>0.05$; Table 2). In the opposite case, Sadowska et al. (2019) found that in contrast to $\mathrm{Pb}, \mathrm{Cd}$ concentration in bee bodies was dependent on environmental contamination. The concentration of $\mathrm{Cd}$ found in bees from the Podkarpackie region was comparable to the results obtained by Fakhimzadeh and Lodenius (2000) for Finnish bees $(0.05-1.2 \mathrm{mg} / \mathrm{kg})$ but significantly higher as compared to Costa et al. (2019; 0.008 $0.195 \mathrm{mg} / \mathrm{kg}$ ), or Perugini et al. (2011; 0.05-0.06 $\mathrm{mg} / \mathrm{kg}$ ) for Italian bees. The content of $\mathrm{Pb}$ in tested bee bodies was comparable to the findings of Porrini et al. (2002) for bees inhabiting the Italian national park $(0.15-0.55 \mathrm{mg} / \mathrm{kg}$ d.m.), and other non-contaminated sites of Italy $(0.25-1.40 \mathrm{mg} / \mathrm{kg}$ d.m.; Costa et al., 2019; Conti and Botre, 2001) as well as in the urban and industrial sites of Belgium (0.33-0.41 mg/kg d.m.; Van Der Steen et al., 2015). Roman (2010) measured cadmium in bee bodies from the industrialized areas of Poland in the range of 1.46 to $2.32 \mathrm{mg} / \mathrm{kg} \mathrm{d.m}$. Thus, compared to the cited authors, the results obtained for $\mathrm{Pb}$ in the present study are in compliance with the data for environmentally pure bees habitats. The Mn content in the tested bees was very variable.
As compared to the literature, the average content in the tested bees was found to be higher than in the study conducted in Poland by Skorbiłowicz et al. (2018) who found a level of $49.4 \mathrm{mg} / \mathrm{kg} \mathrm{d} . \mathrm{m}$. in bees collected in June, and $26.6 \mathrm{mg} . \mathrm{kg} \mathrm{d.m}$. in bees collected in March. In the study carried out by Zhelyazkova (2012) in Bulgaria (in the vicinity of Stara Zagora), the concentration of $\mathrm{Mn}$ in the analysed bees varied between $43-114 \mathrm{mg} / \mathrm{kg}$ d.m. while in the study of Zarić et al. (2016) in Serbia the $\mathrm{Mn}$ concentrations ranged from 34 to $90 \mathrm{mg} / \mathrm{kg}$ d.m. The results obtained are comparable with our previous study focused on the transfer of heavy metals from bees to honey (Dżugan et al., 2018).

\section{Honey contamination by toxic metals}

As the last link in the food chain, honey was tested for the concentration of toxic metals. As expected, our results indicated different levels of toxic metals depending on the honey variety, plant species and region of collection (E and U; Table 2). Moreover, significant differences in the content of particular elements, which were measured in the same honey variety but with different origins were observed. A similar tendency during the testing of heavy metals in different types of Polish honey was reported (Sitarz-Palczak et al., 2015; Dżugan et al., 2017; 2018).

Table 2. Concentration of toxic metals ( $\mathrm{mg} / \mathrm{kg} \mathrm{d} . \mathrm{w}$.) in tested bee body and honey samples collected from ecological (E) and urbanized (U) regions of Podkarpacie. The results are expressed as mean $\pm \mathrm{SD}$ and (min-max) values

\begin{tabular}{|c|c|c|c|c|c|c|c|}
\hline \multicolumn{2}{|r|}{ Sample } & \multirow{2}{*}{$\frac{\text { Area }}{\mathrm{E}}$} & \multirow{2}{*}{$\begin{array}{c}\text { Cd } \\
0.51 \pm 0.54 \\
(0.00-2.41)\end{array}$} & \multirow{2}{*}{$\begin{array}{c}\mathbf{P b} \\
0.12 \pm 0.17 \\
(0.00-0.72)\end{array}$} & \multirow{2}{*}{$\begin{array}{c}\mathbf{A l} \\
12.93 \pm 11.95 \\
(0.00-50.17)\end{array}$} & \multirow{2}{*}{$\begin{array}{c}\text { Mn } \\
109.72 \pm 161.53 \\
(0.01-734.53)\end{array}$} & \multirow{2}{*}{$\begin{array}{c}\mathbf{N i} \\
0.36 \pm 0.41 \\
(0.00-1.45)\end{array}$} \\
\hline \multirow{2}{*}{\multicolumn{2}{|c|}{ ญ्ల }} & & & & & & \\
\hline & & $\mathrm{U}$ & $\begin{array}{c}0.71 \pm 0.84 \\
(0.02-3.19)\end{array}$ & $\begin{array}{c}0.13 \pm 0.19 \\
(0.00-0.77)\end{array}$ & $\begin{array}{l}11.78 \pm 12.93 \\
(1.06-50.70)\end{array}$ & $\begin{array}{c}159.22 \pm 173.19 \\
(5.09-449.86)\end{array}$ & $\begin{array}{c}0.32 \pm 0.31 \\
(0.00-1.06)\end{array}$ \\
\hline \multirow{10}{*}{ 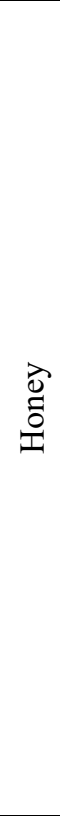 } & \multirow{2}{*}{ Honeydew } & $\mathrm{E}$ & $\begin{array}{c}0.03 \pm 0.01 \\
(0.02-0.04)\end{array}$ & $\begin{array}{c}0.08 \pm 0.12 \\
(0.00-0.31)\end{array}$ & $\begin{array}{l}47.00 \pm 32.78 \\
(2.30-86.29)\end{array}$ & $\begin{array}{c}4.03 \pm 1.606 \\
(1.580-5.875) \\
\end{array}$ & $\begin{array}{c}0.53 \pm 0.47 \\
(0.00-1.49)\end{array}$ \\
\hline & & $\mathrm{U}$ & $\begin{array}{c}0.04 \pm 0.01 \\
(0.02-0.05)\end{array}$ & $\begin{array}{c}0.09 \pm 0.19 \\
(0.00-0.77)\end{array}$ & $\begin{array}{l}54.37 \pm 27.37 \\
(0.36-91.33)\end{array}$ & $\begin{array}{c}4.55 \pm 1.97 \\
(0.16-6.82)\end{array}$ & $\begin{array}{c}0.54 \pm 0.54 \\
(0.00-1.52)\end{array}$ \\
\hline & \multirow{2}{*}{ Goldenrod } & $\mathrm{E}$ & $\begin{array}{c}0.02 \pm 0.01 \\
(0.01-0.03)\end{array}$ & $\begin{array}{c}0.03 \pm 0.04 \\
(0.00-0.08)\end{array}$ & $\begin{array}{c}7.97 \pm 3.93 \\
(0.97-10.06)\end{array}$ & $\begin{array}{c}2.44 \pm 2.72 \\
(0.15-7.14)\end{array}$ & $\begin{array}{l}0.08 \pm 0.11^{\mathrm{a}} \\
(0.00-0.23)\end{array}$ \\
\hline & & $\mathrm{U}$ & $\begin{array}{c}0.02 \pm 0.01 \\
(0.01-0.04)\end{array}$ & $\begin{array}{c}0.02 \pm 0.02 \\
(0.00-0.05)\end{array}$ & $\begin{array}{c}8.63 \pm 7.47 \\
(1.79-16.66)\end{array}$ & $\begin{array}{c}1.29 \pm 0.76 \\
(0.18-1.88)\end{array}$ & $\begin{array}{l}0.55 \pm 0.37^{b} \\
(0.00-0.79)\end{array}$ \\
\hline & \multirow{2}{*}{ Dandelion } & $\mathrm{E}$ & $\begin{array}{c}0.03 \pm 0.01 \\
(0.02-0.05)\end{array}$ & $\begin{array}{c}0.09 \pm 0.09 \\
(0.01-0.40)\end{array}$ & $\begin{array}{c}8.13 \pm 6.57^{\mathrm{a}} \\
(0.00-46.16)\end{array}$ & $\begin{array}{c}3.59 \pm 2.43 \\
(0.28-7.42)\end{array}$ & $\begin{array}{c}0.35 \pm 0.46 \\
(0.00-1.44)\end{array}$ \\
\hline & & $\mathrm{U}$ & $\begin{array}{c}0.02 \pm 0.01 \\
(0.01-0.05)\end{array}$ & $\begin{array}{c}0.04 \pm 0.05 \\
(0.00-0.17)\end{array}$ & $\begin{array}{c}1.72 \pm 2.45^{\mathrm{b}} \\
(0.00-10.29)\end{array}$ & $\begin{array}{c}4.31 \pm 3.83 \\
(0.29-11.34)\end{array}$ & $\begin{array}{c}0.17 \pm 0.27 \\
(0.00-1.02)\end{array}$ \\
\hline & \multirow{2}{*}{ Rapeseed } & $\mathrm{E}$ & $\begin{array}{c}0.02 \pm 0.00 \\
(0.02-0.02)\end{array}$ & n.d. & $\begin{array}{c}1.81 \pm 1.73 \\
(0.47-4.65)\end{array}$ & $\begin{array}{c}0.26 \pm 0.08 \\
(0.18-0.36)\end{array}$ & $\begin{array}{c}0.72 \pm 0.34 \\
(0.14-0.97)\end{array}$ \\
\hline & & $\mathrm{U}$ & $\begin{array}{c}0.01 \pm 0.01 \\
(0.01-0.03)\end{array}$ & $\begin{array}{c}0.04 \pm 0.05 \\
(0.00-0.12)\end{array}$ & $\begin{array}{c}2.85 \pm 2.36 \\
(0.48-5.61)\end{array}$ & $\begin{array}{c}0.46 \pm 0.12 \\
(0.34-0.63)\end{array}$ & $\begin{array}{c}0.70 \pm 0.56 \\
(0.00-1.12)\end{array}$ \\
\hline & \multirow{2}{*}{ Tilia } & $\mathrm{E}$ & $\begin{array}{c}0.04 \pm 0.03 \\
(0.02-0.07)\end{array}$ & $\begin{array}{c}0.04 \pm 0.01 \\
(0.02-0.05)\end{array}$ & $\begin{array}{c}2.35 \pm 0.85 \\
(1.37-2.89)\end{array}$ & $\begin{array}{l}2.22 \pm 1.39^{\mathrm{a}} \\
(0.71-3.43)\end{array}$ & $\begin{array}{l}0.17 \pm 0.07^{\mathrm{a}} \\
(0.10-0.24)\end{array}$ \\
\hline & & $\mathrm{U}$ & $\begin{array}{c}0.02 \pm 0.00 \\
(0.02-0.02)\end{array}$ & $\begin{array}{c}0.02 \pm 0.02 \\
(0.01-0.05)\end{array}$ & $\begin{array}{c}1.97 \pm 0.94 \\
(1.19-3.01)\end{array}$ & $\begin{array}{l}0.90 \pm 0.47^{b} \\
(0.39-1.33)\end{array}$ & $\begin{array}{l}0.63 \pm 0.85^{\mathrm{b}} \\
(0.05-1.66)\end{array}$ \\
\hline
\end{tabular}

$\mathrm{a}, \mathrm{b}-$ means with various letters are significantly different $(\mathrm{p}<0.05)$ between the $\mathrm{E}$ and $\mathrm{U}$ region in particular biological materials 
The Cd content in the tested honeys varied from 0.01 to $0.07 \mathrm{mg} / \mathrm{kg}$ whereas for $\mathrm{Pb}$ it varied from 0.00 to $0.77 \mathrm{mg} / \mathrm{kg}$. The observed $\mathrm{Cd}$ values were generally within the allowable limits set out in the Polish Regulations of the Minister of Health (2003), which permits a level of 0.03 and 0.30 $\mathrm{mg} / \mathrm{kg}$ for $\mathrm{Cd}$ and $\mathrm{Pb}$, respectively. An excess of cadmium was noted in 5\% of the samples (2 honeydew, 2 dandelion and 1 tilia) whereas only 2 honeydew honey samples contained too much lead. In general, the metal content in honey that originated from the $\mathrm{E}$ and $\mathrm{U}$ areas were comparable. More differences with regard to the honey variety were observed, i.e. honeydew honey contained higher levels of $\mathrm{Al}$ and $\mathrm{Mn}$, whereas rapeseed honey was abundant in nickel. As compared to the literature, significantly higher concentrations of $\mathrm{Pb}$ than in the present study were described by Sitarz-Palczak et al. (2015) for Polish honeydew honey and multifloral honey (1.95-39.0 and $0.97-4.97 \mathrm{mg} / \mathrm{kg}$, respectively). Aghamirlou et al. (2015) tested multifloral honey from Iran and found comparable results to the present study for levels of $\mathrm{Pb}(0.45 \mathrm{mg} / \mathrm{kg})$ but lower levels of $\mathrm{Cd}$ $(0.013 \mathrm{mg} / \mathrm{kg})$, and higher levels of $\mathrm{Ni}(0.87$ $\mathrm{mg} / \mathrm{kg}$ ). Oroian et al. (2016) tested for heavy metals in multifloral Romanian honey and found lower levels of $\mathrm{Cd}$ and $\mathrm{Mn}(0.003$ and 1.001 $\mathrm{mg} / \mathrm{kg})$ but comparable levels of $\mathrm{Ni}$ and $\mathrm{Pb}(0.183$ and $0.04 \mathrm{mg} / \mathrm{kg}$ ). Moreover, the same authors observed different concentrations of the tested elements depending on the honey type.

\section{Heavy metals transfer in the studied food chain}

An analysis of the average content of the tested elements in individual links in the food chain showed the occurrence of the migration of these elements from the soil to the bodies of bees (Table 3). In the case of $\mathrm{Pb}$ and $\mathrm{Mn}$, a significant decrease was observed in the individual subsequent parts of the food chain. The comparable levels of $\mathrm{Al}$ and $\mathrm{Ni}$ in bees and honey indicate that these metals are not accumulated by bees and that they do not constitute a biological barrier limiting the migration of these metals in the food chain. Meanwhile, based on the detected levels of $\mathrm{Cd}$ and $\mathrm{Pb}$ in the individual links of the tested food chain it was proven that bees are susceptible to the bioaccumulation of $\mathrm{Cd}$ and $\mathrm{Pb}$ and simultaneously that they function as an effective biological barrier preventing the transference of such elements to the honey.

In order to check for the potential of bioaccumulation of toxic metals by individual plant species, the bioaccumulation factor was calculated (Table 4). The results obtained, despite the high degree of variability, indicate that the phenomenon of bioaccumulation is particularly relevant to cadmium $(\mathrm{BF} \geq 1)$, and the plants that particularly intensively absorb this element from the soil are: dandelion and goldenrod, while the least absorbing one is rapeseed plant. The ratio of the concentration of pollutants in the plant and soil can be used as an approximate indicator of the level of element transfer from soil to plant (Kabata-Pendias \& Pendias, 2001; Ehlken and Kirchner, 2002). The soil to plant transfer intensity depends primarily on the concentration of trace metals in the soil, but also on soil $\mathrm{pH}$, specific metals availability in the soil and on the interaction with other cations (Kabata-Pendias \& Pendias, 2001; Ehlken \& Kirchner, 2002; Probst et al., 2009).

Based on the calculated coefficients of heavy metals migration from soil to plants, with the help of special software, maps of the Podkarpackie Voivodeship designating areas which are most exposed to heavy metal contamination have been created (Figure 1). Such maps can be useful for the local beekeeping sector.

Table 3. Migration of toxic metals in the soil-plant-bee-honey chain

\begin{tabular}{|c|c|c|c|c|}
\hline Element & Soil & Plants & Bees & Honey \\
\hline \multirow{2}{*}{$\mathrm{Cd}$} & $0.37 \pm 0.27^{\mathrm{b}}$ & $0.40 \pm 0.34^{\mathrm{b}}$ & $0.63 \pm 0.72^{\mathrm{b}}$ & $0.02 \pm 0.01^{\mathrm{a}}$ \\
& $(0.04-1.25)$ & $(0.03-1.74)$ & $(0.02-3.19)$ & $(0.00-0.07)$ \\
\hline \multirow{2}{*}{$\mathrm{Pb}$} & $21.30 \pm 9.57^{\mathrm{a}}$ & $0.52 \pm 0.49^{\mathrm{b}}$ & $0.13 \pm 0.18^{\mathrm{c}}$ & $0.05 \pm 0.10^{\mathrm{d}}$ \\
& $(9.23-58.07)$ & $(0.00-2.02)$ & $(0.00-0.77)$ & $(0.00-0.77)$ \\
\hline \multirow{2}{*}{$\mathrm{Al}$} & $2552.60 \pm 596.69^{\mathrm{c}}$ & $244.13 \pm 225.94^{\mathrm{b}}$ & $12.59 \pm 12.36^{\mathrm{a}}$ & $11.64 \pm 19.88^{\mathrm{a}}$ \\
& $(1598.73-3789.73)$ & $(20.60-803.19)$ & $(1.06-50.70)$ & $0.00-91.33$ \\
\hline \multirow{2}{*}{$\mathrm{Mn}$} & $528.93 \pm 255.72^{\mathrm{a}}$ & $291.13 \pm 378.38^{\mathrm{b}}$ & $138.56 \pm 168.35^{\mathrm{c}}$ & $3.39 \pm 2.89^{\mathrm{d}}$ \\
& $(56.44-1063.72)$ & $(19.92-1425.68)$ & $(5.09-734.53)$ & $(0.15-16.72)$ \\
\hline \multirow{2}{*}{$\mathrm{Ni}$} & $1.63 \pm 4.02$ & $1.28-2.09$ & $0.34 \pm 0.36$ & $0.45 \pm 0.54$ \\
& $(0.00-16.18)$ & $(0.00-8.99)$ & $(0.00-1.45)$ & $0.00-2.43)$ \\
\hline
\end{tabular}

a,b,c,d - different letters indicate significant differences $(\mathrm{p}<0.05)$ in the table row 
Table 4. Bioaccumulation factor $(\mathrm{BF})$ of selected toxic metals in the analysed plant species with regard to the pollution area (E-ecological, U-urbanized)

\begin{tabular}{|l|c|c|c|c|c|c|}
\hline \multicolumn{1}{|c|}{ Plant } & Area & $\mathbf{C d}$ & $\mathbf{P b}$ & $\mathbf{A l}$ & $\mathbf{M n}$ & $\mathbf{N i}$ \\
\hline \multirow{2}{*}{ Fir (Abies alba Mill) } & $\mathrm{E}$ & $0.74 \pm 0.69$ & $0.05 \pm 0.07$ & $0.19 \pm 0.24$ & $1.28 \pm 1.54$ & $1.70 \pm 0.77$ \\
\cline { 2 - 7 } & $\mathrm{U}$ & $1.43 \pm 1.23$ & $0.03 \pm 0.05$ & $0.17 \pm 0.56$ & $1.03 \pm 1.99$ & $1.39 \pm 0.44$ \\
\hline $\begin{array}{l}\text { Goldenrod } \\
\text { (Solidago) }\end{array}$ & $\mathrm{E}$ & $1.23 \pm 1.07$ & $0.03 \pm 0.02$ & $0.05 \pm 0.13$ & $0.24 \pm 0.42^{\mathrm{a}}$ & $0.01 \pm 0.01$ \\
\cline { 2 - 7 } $\begin{array}{l}\text { Dandelion } \\
\text { (Taraxacum officinale) }\end{array}$ & $\mathrm{U}$ & $2.20 \pm 0.65$ & $0.03 \pm 0.03$ & $0.05 \pm 0.10$ & $1.02 \pm 1.01^{\mathrm{b}}$ & $0.07 \pm 0.06$ \\
\cline { 2 - 7 } $\begin{array}{l}\text { Rapeseed } \\
\text { (Brassica } \text { napus) }\end{array}$ & $\mathrm{E}$ & $1.64 \pm 2.20$ & $0.02 \pm 0.05$ & $0.10 \pm 0.27$ & $0.10 \pm 0.08$ & $1.53 \pm 0.82$ \\
\hline $\begin{array}{l}\text { Tilia } \\
\text { (Tilia) }\end{array}$ & $\mathrm{E}$ & $0.38 \pm 0.14$ & $0.00 \pm 0.01$ & $0.01 \pm 0.03$ & $0.05 \pm 0.03$ & $0.24 \pm 0.22$ \\
\cline { 2 - 7 } & $\mathrm{U}$ & $0.57 \pm 0.77$ & $0.00 \pm 0.01$ & $0.02 \pm 0.06$ & $0.08 \pm 0.07$ & $0.20 \pm 0.18$ \\
\cline { 2 - 7 } & $\mathrm{E}$ & $0.42 \pm 0.69$ & $0.01 \pm 0.02$ & $0.02 \pm 0.03$ & $0.20 \pm 0.18$ & n.t. \\
\hline
\end{tabular}

a,b - different letters indicate significant differences $(\mathrm{p}<0.05)$ between particular plants collected from the $\mathrm{E}$ and $\mathrm{U}$ region
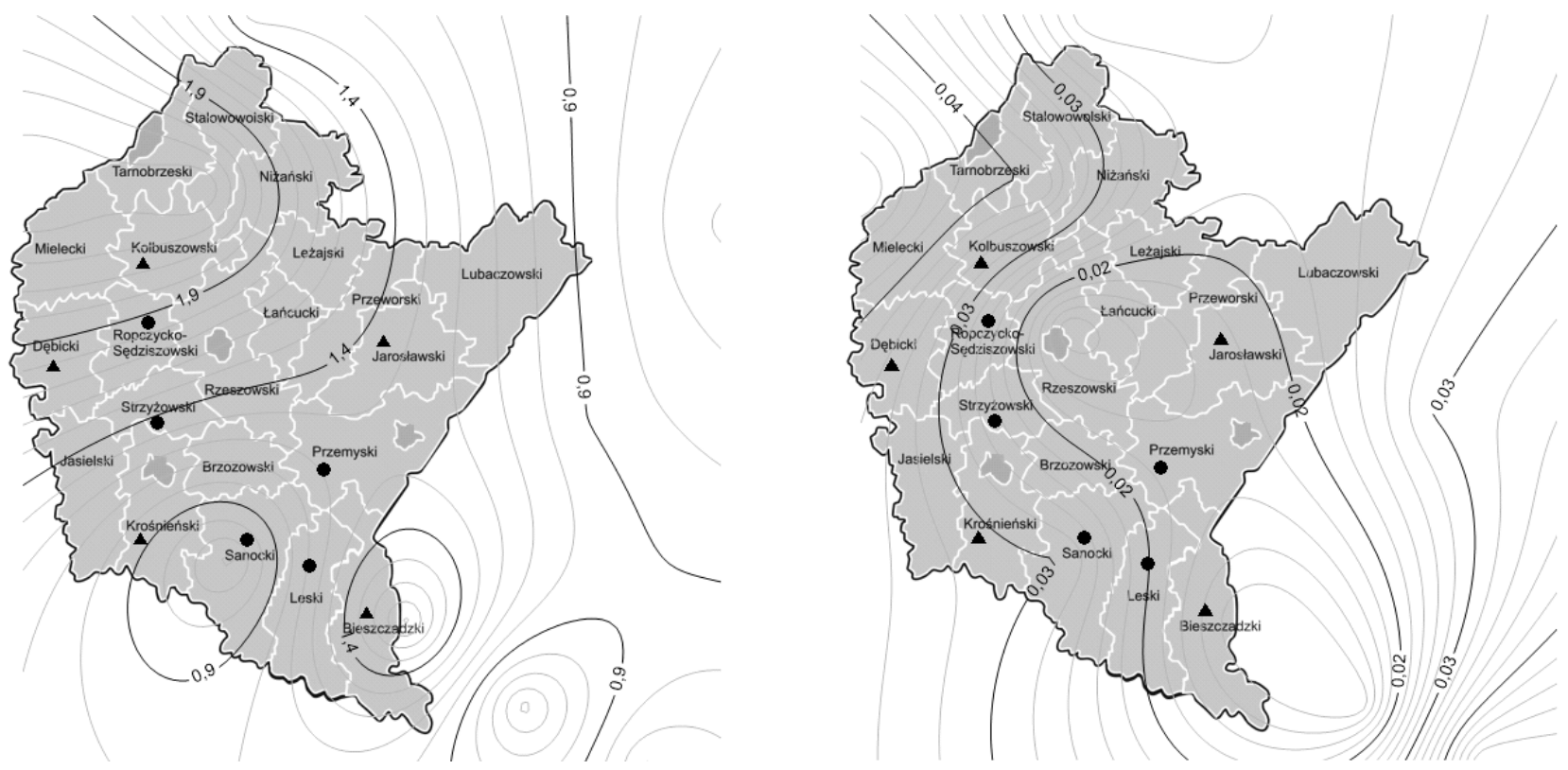

Figure 1. Map of the Podkarpackie Voivodeship with the marked areas of increased migration of Cd (left) and $\mathrm{Pb}(\mathrm{right})$ from soil to plants. The sampling points (apiaries) were indicated for $\mathrm{E}(\boldsymbol{\Delta})$ and $\mathrm{U}(\bullet)$ areas.

\section{CONCLUSIONS}

Studies have shown the occurrence of heavy metal migration in the soil-plant-bee-honey food chain, with particular reference to cadmium. Melliferous plants accumulate heavy metals to a small extent, with the exception of cadmium. From all of the tested varieties of plants, goldenrod and dandelion were confirmed as cadmium accumulators. The bodies of bees are an effective barrier to the migration of heavy metals from the environment to honey, because of this, the honey is free from pollution and safe for human consumption.

\section{ACKLOWNEDGMENTS}

The work was partially supported by the program of the Minister of Science and Higher Education entitled "Regional Initiative of Excellence“ in 2019-2022 (Project no. 026/RID/2018/19).

\section{REFERENCES}

1. Afzal, S., Abdul, N., Nazeef, U., Ali, R., Muhammad, A., Muhammad, Z. \& Muhammad S.K. (2013). Comparative study of heavy metals in soil and selected medicinal plants. Journal of Chemistry, article ID 621265, 5 pages. DOI:10.1155/2013/621265. 
2. Aghamirlou, H.M., Khadem, M., Rahmani, A., Sadeghian, M., Mahvi, A. H., Akbarzadeh, A. \& Nazmara, S. (2015). Heavy metals determination in honey samples using inductively coupled plasmaoptical emission spectrometry. Journal of Environmental Health Science \& Engineering, 13, 39. DOI:10.1186/s40201-015-0189-8

3. Al Naggar, Y., Naiem, E., Mona, M. \& Seif, A. (2013). Honey bees and their products as a bioindicator of environmental pollution with heavy metals. Mellifera, 13(26), 10-20.

4. Ali, H., Khan, E. \& Ilahi, I. (2019). Environmental chemistry and ecotoxicology of hazardous heavy metals: environmental persistence, toxicity, and bioaccumulation. Journal of Chemistry, Article ID 6730305, 14 pages. DOI:10.1155/2019/6730305.

5. Angelova, V.R., Ivanova, R.I., Todorov, J.M. \& Ivanov, K.I. (2017). Potential of rapeseed (Brassica napus L.) for phytoremediation of soils contaminated with heavy metals. Journal of Environmental Protection and Ecology, 18(2), 468-478.

6. Besser, J.M., Brumbaugh, W.G. \& Ingersoll, C.G. (2015). Characterizing toxicity of metal contaminated sediments from mining areas. Applied Geochemistry, 57, 73-84. DOI:10.1016/j.apgeochem.2014.05.021

7. Buczkowski, R., Kondzielski, I. \& Szamański, T. (2002). Methods of remediation of soil contaminated by heavy metals. Mikołaj Kopernik University Editions, Torun, First Edition, pp. 1-110.

8. Burden, C.M., Morgan, M.O., Hladun, K.R., Amdam, G.V., Trumble, J.J. \& Smith, B.H. (2019). Acute sublethal exposure to toxic heavy metals alters honey bee (Apis mellifera) feeding behavior. Scientific reports, 9(1), Article ID 4253. DOI:10.1038/s41598-019-40396-x

9. Conti, M.E. \& Botrè, F. (2001). Honeybees and their products as potential bioindicators of heavy metals contamination. Environmental Monitoring Assessment, 69(3), 267-282. DOI:10.1023/A:1010719107006

10. Costa, A., Veca, M., Barberis, M., Tosti, A., Notaro, G., Nava, S., Lazzari, M., Agazzi, A. \& Tangorra, F.M. (2019). Heavy metals on honeybees indicate their concentration in the atmosphere-a proof of concept. Italian Journal of Animal Science, 18(1), 309-315. DOI:10.1080/1828051X.2018.1520052

11. Dabkowska-Naskret, H., Różański, S. \& Bartkowiak, A. (2016). Forms and mobility of trace elements in soils of park areas from the city of Bydgoszcz, north Poland. Soil Science Annual, 67(2), 73-78. DOI:10.1515/ssa-2016-0010.

12. Diatta, J., Biber, M., Przygocka-Cyna, M. \& Łukowiak, R. (2011). Application of soil-plant transfer coefficients and plant pollution indices for evaluating heavy metal contamination within the Marcinkowski's Recreational Park (Poznań). Nauka Przyroda Technologie, 5(5), 79-86.

13. Draszawka-Bołzan, B. (2015). Heavy Metals in Soils. World News of Natural Sciences, 2, 20-37.

14. Dżugan, M., Wesołowska, M., Zaguła, G., Kaczmarski, M., Czernicka, M. \& Puchalski, C. (2018). Honeybees (Apis mellifera) as a biological barrier for contamination of honey by environmental toxic metals. Environmental Monitoring and Assessment, 190(2), 101. DOI:10.1007/s10661-018-6474-0

15. Dżugan, M., Zaguła, G., Wesołowska, M., Sowa, P. \& Puchalski, C. (2017). Levels of toxic and essential metals in varietal honeys from Podkarpacie. Journal of Elementology, 22(3), 1039-1048. DOI:10.5601/jelem.2016.21.4.1298

16. Ehlken, S. \& Kirchner, G. (2002). Environmental processes affecting plant root uptakeof radioactive trace elements and variability of transfer factor data: a review. Journal of Environmental Radioactivity, 58(2-3), 97-112. DOI:10.1016/S0265-931X(01)00060-1

17. Fakhimzadeh, K. \& Lodenius, M. (2000). Heavy metals in Finnish honey, pollen and honey bees. Apiacta, 35(2), 85-95.

18. Filipović-Trajković, R., Ilić, Z.S., Šunić, L. Andjelković, S. \& (2012). The potential of different plant species for heavy metals accumulation and distribution. Journal of Food, Agriculture \& Environment, 10(1), 959-964.

19. Gandois, L. \& Probst, A. (2012). Localisation and mobility of trace metal in silver fir needles. Chemosphere, 87(2), 204-210. DOI:10.1016/j.chemosphere.2011.12.020

20. Gostin, I. (2010). Structural changes in silver fir needles in response to air pollution. Analele Universităţii din Oradea - Fascicula Biologie, 17(2), 300-305.

21. Jin, Y., Luan, Y., Ning, Y. \& Wang, L. (2018). Effects and mechanisms of microbial remediation of heavy metals in soil: a critical review. Applied Sciences, 8, Article ID 1336. DOI:10.3390/app8081336

22. Kabata-Pendias, A. \& Pendias, H. (2001). Trace elements in soils and plants. CRC Press Taylor \& Francis Group, pp. 1-106. 
23. Kajka, K. \& Rutkowska, B. (2018). Accumulation of selected heavy metals in soils and common dandelion (Taraxacum officinale) near a road with high traffic intensity. Soil Science Annual, 69(1/2018), 11-16. DOI:10.2478/ssa-2018-0002

24. Klotz K1, Weistenhöfer W, Neff F, Hartwig A, van Thriel C, Drexler H. (2017). The health effects of aluminum exposure. Deutsches Ärzteblatt International, 14(39), 653-659. DOI: 10.3238/arzteb1.2017.0653.

25. Ligocki, M., Tarasewicz, Z., Zygmunt, A. \& Aniśko, M. (2011). The common dandelion (Taraxacum officinale) as an indicator of anthropogenic toxic metal pollution of environment. Acta Scientiarum Polonorum, Zootechnica, 10(4), 73-82.

26. Mirecki, N., Agič, R., Šunić, L., Milenković, L. \& Ilić, Z.S. (2015). Transfer factor as indicator of heavy metals content in plants. Fresenius Environmental Bulletin, 24(11), 4212-4219.

27. Miskowiec, P., Łaptaś, A. \& Zięba, K. (2015). Soil pollution with heavy metals in industrial and agricultural areas: A case study of Olkusz District. Journal of Elementology, 20(2), 353-362. DOI:10.5601/jelem.2014.19.3.691

28. Niedźwiecka, A. \& Zamorska-Wojdyła, D. (2017). The bioaccumulation of heavy metals in Brassica napus L. in the area around Turów Power Station, Poland. E3S Web of Conferences 17, Article ID 00065. DOI:10.1051/e3sconf/20171700065

29. Oroian, M., Prisacaru, A., Hretcanu, E.C., Stroe, S.G., Leahu, A. \& Buculei, A. (2016). Heavy metals profile in honey as a potential indicator of botanical and geographical origin. International Journal of Food Properties, 19(8), 1825-1836. DOI:10.1080/10942912.2015.1107578

30. Perugini, M., Manera, M., Grotta, L., Abete, M.C., Tarasco, R. \& Amorena, M. (2011). Heavy metal $(\mathrm{Hg}, \mathrm{Cr}, \mathrm{Cd}$, and $\mathrm{Pb})$ contamination in urban areas and wildlife reserves: honeybees as bioindicators. Biological Trace Element Research, 140(2), 170-176. DOI:10.1007/s12011-010-8688-z

31. Petryk, A. (2016). Assessment of the content of heavy metals in plants and soil in the Trzebinia municipality, Poland. 4.copper. Infrastructure and Ecology of Rural Areas, 4(4), 1711-1721. DOI:10.14597/infraeco.2016.4.4.128

32. Porrini, C., Ghini, S., Girotti, S., Sabatini, A.G., Gattavecchia, E. \& Celli, G. (2002). Use of honey bees as bioindicators of environmental pollution in Italy. In J. Devillers J, Pham-Delègue MH (Eds), Honey bees: estimating the environmental impact of chemicals. New York: Taylor \& Francis, pp. 187-247.

33. Probst, A., Liu, H., Fanjul, M., Liao, B. \& Hollande, E. (2009). Response of Vicia faba L. to metal toxicity on mine tailing substrate: geochemical and morphological changes in leaf and root. Environmental and Experimental Botany, 66(2), 297-308. DOI:10.1016/j.envexpbot.2009.02.003

34. Polish regulation of the Minister of Health (2003). Regulation on the maximum levels of chemical and biological contaminants that may be found in foods, food ingredients, authorized additives, processing aids or on the surface of foods. Poland, Warsaw. Dz.U.03.37.326.

35. Polish regulation of the Minister of Environment (2002). Regulation on soil quality standards and standards of ground quality. Poland, Warsaw. Dz.U.02.165.1359.

36. Reszel, R., Reszel, H., Pęcak J. \& Hadam, B. (2003). The content of sulfur and heavy metals in soils of agricultural land and plants of protected areas of the Podkarpackie Voivodship. In: J. A. Tomaszek (Ed.), Postęp w inżynierii środowiska, Oficyna Wydawnicza Politechniki Rzeszowskiej, Rzeszów, pp. 435-445. (in Polish)

37. Roman, A. (2010). Levels of copper, selenium, lead, and cadmium in forager bees. Polish Journal of Environmental Studies, 19(3), 663-669.

38. Sadowska, M., Gogolewska, H., Pawelec, N., Sentkowska, A. \& Krasnodębska-Ostręga, B. (2019). Comparison of the contents of selected elements and pesticides in honey bees with regard to their habitat. Environmental Science and Pollution Research, 26(1), 371-380. DOI:10.1007/s11356-018$3612-8$

39. Šijacic-Nikolic, M., Stankovic, D., Krstic, B., Vilotic, D. \& Ivetic, V. (2012). The potential of different lime tree (Tilia spp) genotypes for phytoextraction of heavy metals. Genetika, 44(3), 537-548. DOI:0.2298/GENSR1203537S

40. Sitarz-Palczak, E. (2015). Evaluation of the content of selected heavy metals in samples of Polish honeys. Journal of Ecological Engineering, 16(3), 130-138. DOI:10.12911/22998993/2946

41. Skorbiłowicz, E., Skorbiłowicz, M. \& Cieśluk, I. (2018). Bees as bioindicators of environmental pollution with metals in an urban area. Journal of Ecological Engineering, 19(3), 229-234. DOI: $10.12911 / 22998993 / 85738$ 
42. Smical, A.I., Vasile, H., Oros, V., Juhasz, J. \& Pop, E. (2008). Studies on transfer and bioaccumulation of heavy metals from soil into lettuce. Environmental Engineering and Management Journal, 7(5), 609615. DOI:10.30638/eemj.2008.085

43. Tomašević, M., Rajšić, S., Dordević, D., Tasić, M., Krstić, J. \& Novakovic, V. (2004). Heavy metals accumulation in tree leaves from urban areas. Environmental Chemistry Letters, 2(3), 151-154. DOI:10.1007/s10311-004-0081-8

44. Tóth, M.D., Balázsy, S., Terek, O., Patsula, O., Halász, J.L., Simon, L., Koncz, J. \& Anton, A. (2012). Study of the chromium, cadmium, copper, zinc contents of soil and dominant plant species in the floodplain of Upper-Tisza area. Studia Universitatis ,,Vasile Goldiş”, Seria Ştiinţele Vieţii, 22(2), 265274.

45. Van der Steen, J.J.M., Kraker, J. \& Grotenhuis, T. (2015). Assessment of the potential of honeybees (Apis mellifera L.) in biomonitoring of air pollution by cadmium, lead and vanadium. Journal of Environmental Protection, 6(2), 96-102. DOI:10.4236/jep.2015.62011

46. Violante, A., Cozzolino, V., Perelomov, L., Caporale, A.G. \& Pigna, M. (2010). Mobility and bioavailability of heavy metals and metalloids in soil environments. Journal of Soil Science and Plant Nutrition, 10(3), 268 - 292. DOI:10.4067/S0718-95162010000100005

47. Yan, X., Liu, M., Zhong, J., Guo, J. \& Wu, W. (2018). How human activities affect heavy metal contamination of soil and sediment in a long-term reclaimed area of the Liaohe River Delta, North China. Sustainability, 10(2), Article ID 338. DOI:10.3390/su10020338

48. Yu, R., Ji, J., Yuan, X., Song, Y. \& Wang, C. (2011). Accumulation and translocation of heavy metals in the canola (Brassica napus L.) - soil system in Yangtze River Delta, China. Plant Soil, 353(1-2), 3345. DOI:10.1007/s11104-011-1006-5

49. Zarić, N.M., Ilijević, K., Stanisavljević, L. \& Grźetić, I. (2016). Metal concentrations around thermal power plants, rural and urban areas using honeybees (Apis mellifera L.) as bioindicators. International Journal of Environmental Science and Technology, 13(2), 413-422. DOI:10.1007/s13762-015-0895-x

50. Zhelyazkova, I. (2012). Honeybees-bioindicators for environmental quality. Bulgarian Journal of Agricultural Science, 18(3), 435-442. 